\title{
Involving social participation in the preservation of heritage: the experience of Greater Poland and Kujavia
}

\author{
R. Barelkowski \\ University of Economy Bydgoszcz (WSG), Poland
}

\begin{abstract}
Architectural heritage is a substantial component of every nation's culture, on both a national and local level. Each piece of architecture has its material and immaterial impact - even if relatively small - on our understanding of the entire culture, the social perception of culture and the meaning it carries for the local identity. To preserve architectural heritage efficiently, especially when dealing with small remote heritage sites, a research program involves social participation intended to program the reuse of the object and its surrounding. The investigation for reasons to initiate or hold intervention has to take into account cultural, educational and economic aspects alike, as equally significant. From the economic perspective, the creation of a strong connection between a society and pieces of heritage may be the last chance for many forgotten architectural objects, otherwise doomed to destruction.
\end{abstract}

Keywords: social and economic aspects in heritage, social participation, preservation strategies.

\section{Expanding the subject of preservation}

The objects of architectural heritage exist in and influence our socio-spatial environment. At least in two ways they directly affect our landscape and contemporary culture as well as contemporary society - by its historical values, manifested in an imaginary representation of these pieces of heritage, and by its physical presence, evoking associations and visions of the past.

Focusing on architecture, we have to approach the problem of heritage in a more specific manner, both disciplinary and interdisciplinary, nevertheless architecture-oriented, to discover that both material and immaterial aspects of its 
influence on our perception of culture and history are especially effective. Material evidence provides the opportunity to explore, to research, to touch, to acquire clues to understand the past. But definitely our understanding of the past is required not only to indulge our annalistic inclinations, but - what may be seen as much more important - to allow us to understand the present and attempt to guide the future. Herewith, immaterial aspects of functioning of objects of architecture are exposed, while they refer to both individual and social imagination of history, people's concept on the influence that historical events, achievements and traces of culture (including the architecture) had and have on their life and the life of a particular group and nation. Finally, but not depleting the list, they have an extraordinary impact on the social concept of identity and orientation - both in cultural and spatial terms.

There are, however, many problems which pieces of architectural heritage must confront in order to maintain their task and retain their influence. Merciless selection related to rational optimization of spending public funds to protect the heritage, the pressure of urbanization and dynamic changes in land use and extensive exploitation affect historical architectural objects. These factors force conservators to struggle constantly between conforming the standards of exposing and allowing to access in order to maintain interest on one hand, and, on the other hand, preserving original structures, protecting architecture against slow but gradual destruction being the result of frequent visiting. While the above mentioned problems are well identifiable in every case, they often seem to seal the fate of the smallest and "weakest" objects, necessary to make our cultural landscape fully comprehended; to bring it to completeness.

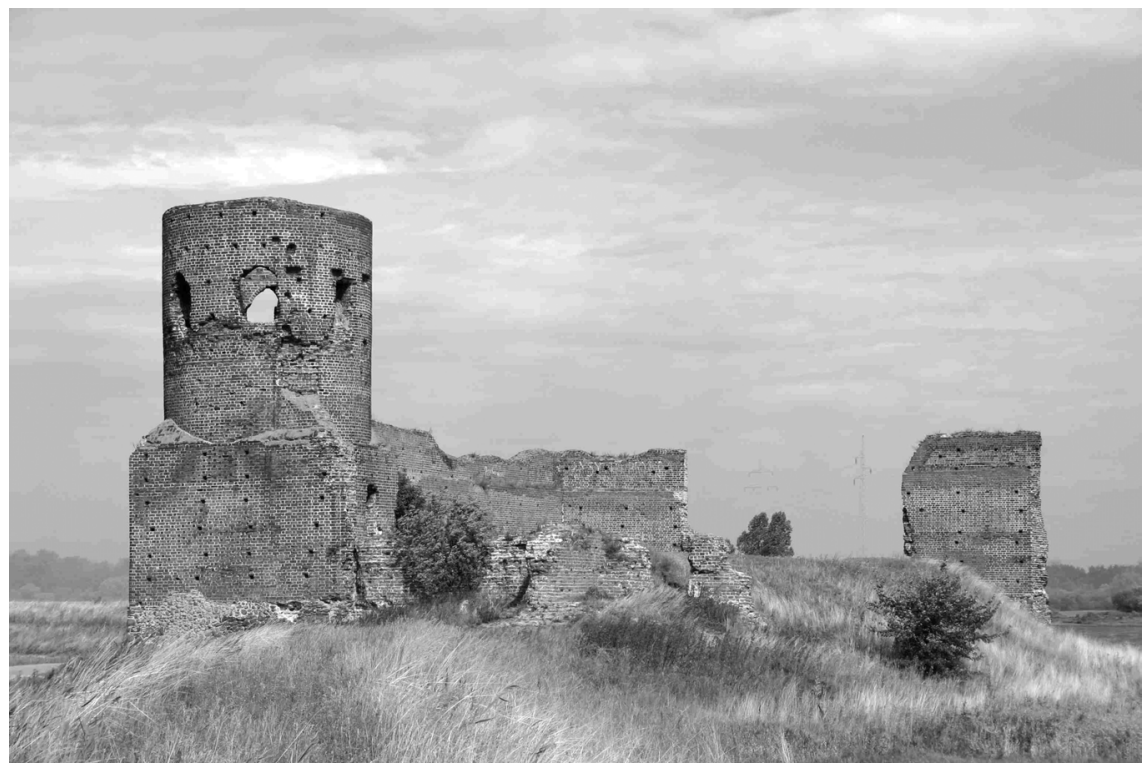

Figure 1: The castle in Kolo, photo: RB. 
The work described in this article focuses on a specific group of architectural objects - medieval castles which are not among the most spectacular buildings. Instead, they form a group of diverse sites, some of them in a state of ruin, massive but without current function, others barely standing, marking their presence with few wall sections or even few bricks only, finally those which are hidden under ground, covered by a mound or simply leaving the area void.

The research program "The Forms of Preservation and Activation of Relics of Medieval Castles in Greater Poland and Kujavia" is concentrated on eleven sites in two regions, providing a variety of contemporary situations, preservation conditions and formal status affecting the efficiency of any intervention or protective activities. The selection was restricted to locations which are not particularly recognized as primary places of architectural heritage. The latter is directly connected with the assumption of examining the relationship between these sites (and respected architectural objects or relics) with local societies. At the same time, a general idea of linking preservation to the requirements of local identities has been taken into account.

All objects included in the research cannot be claimed as spectacular and only two of them are nationally recognizable. This deficiency is a result of failure to sustain the presence of the object in social space as well as in social consciousness. But every single place is related to important, if not crucial, contents of local history, with strong share in the formation of social framework for subsequent generations experience. Eleven places contained five locations in Greater Poland - Ostrorog, Danaborz, Boryslawice Zamkowe, Przedecz, and Kolo, and six locations in Kujavia - Grodek, Szubin, Kruszwica, Starogrod, Wenecja, and Papowo Biskupie. The research was focused on the architectural and spatial means of preservation, integrating social and physiographical aspects. Preservation itself, attributed with the term "intervention" gained an extended meaning, referring to physical preservation of the substance, cultural preservation in both memory and imagination of inhabitants of a local area as well as visitors, finally creating a strong bond between a local community and the pieces of heritage regardless of their ownership status (whether castles became private or remain owned by the state). This shift of terminology is also significant, while it clearly indicates the assumption that protection of original objects may require - sometimes, and if justified - putting aside the principles of conservation, included in some of the most important documents like the Venice Chart and its consequent manifestoes. In the opinion of the members of the research team, the effort had and has to provide the answer how far we can go when considering the contradiction between the rules and the objects, between following the guidelines and following common sense in finding proper means of preservation.

\section{The shift in the methodology of conservation}

The research brought forth several important issues. First, the fundamental dilemma was revealed, confronting canonic methodologies for conservation activities with requirements of diverse characters of individual locations. Instead 
of attempting to fit particular methodologies, conditions in all sites suggested an approach that hardly could be found in any of the available strict groups of rules. Neither referring to general guidelines of charts and programmatic documents was possible in a satisfying way, nor detailed scientific methods, like those elaborated by Malachowicz [1] or discussed by Jokilehto [2], could be applied, without being vastly altered. Similar problem was met with preceding research, conducted by Barelkowski on Castle Hill in Poznan, when redefinition of methodology of restitution was the starting point to found a new mechanism of intervention [3].

The technical conditions as well as available structure and available sources of information limited thinkable support these selected objects could ever get in a competition with others, more spectacular, more rich in evident historical pieces and found exhibits. It raises the question of the aim of the conservation. What shall be preserved? How? And the most important - for what purpose? Thus, as explained by Barelkowski [4] among other similar voices, conservation efforts are dedicated to save the heritage for the benefit of future societies, to retain chances to investigate and know history better using future (better) techniques and methodologies, to maintain, exhibit and explain the importance of ancient ruins or buildings to our successors. As a result of this assumption, social impact of monumental objects has been considered as at least equally important as exclusive and autonomous historical value of the object regarded as detached from its environment. The social trace is the subject of conservators' discourse for some time, but most times this issue is presented as secondary in comparison with the value of the (physical) object. Meanwhile human-centred approach encourages the shift in hierarchy of criteria and situates the social issue as a core subject in considering the aim and the idea behind preservation activities.

When social issue is found as second, third comes the idea of connecting historical architectural object as a content of cultural identity with social identity nested in a specific place. The aspect of identity provides a critical basis for the evaluation of many guidelines formulated among people involved in preservation. While many researchers still see the principles of conservation concentrated on objects or spaces, from viewpoints presented by others, like Luxen [5] commenting on the increasing role of social and economical conditions affecting the practice of conservation or more adequate conclusion by Benedetti, who claims the necessity to adjust guidelines from the Venice Chart and other documents to elaborate site-specific related methods of intervention and preservation [6]. A decade before the above-mentioned voices were recorded in the Cracow Chart, Bogdanowski presented his thoughts on the problem of values and their interpretation in architectural heritage [7]. The social aspect is clearly indicated and the urge to define the aims and the idea of conservation in a wider sense than simple physical protection is also expressed, despite a conservative approach to the problem of allowed methodologies, which does not convey the same message. 


\section{Understanding and transforming social background}

What can be done with places like those that are contained in the research program? With objects like Ostrorog, with nothing more than presumable ruins hidden for decades now under ground and affecting the landscape with its height and mass of the mound only? With scarcely few bricks remaining on sites in Grodek, Danaborz and Szubin?

In the opinion of the research team, the observed results of implementation of the previous doctrine on conservation, focused on the object, prove to be inefficient, if not disastrous, when these particular places are taken into account. And locations in Szubin, Wenecja or Boryslawice Zamkowe have rich history and - in the past - proved to play an unparalleled role in cementing social ties. Especially for Poland, due to regaining independence in 1918, they were often focal points of reference for social understanding of tradition and remembrance. The words of warning spoken by Bogdanowski [7] on dangers of idealizing and thus altering the concept of the past are valid, but should not dominate the discussion. The arguments on distorting the view of the past are significant only as long as the place exists - and lack of any activities, exposure to urbanization processes, unavailability of financial support (caused by absence in social space, and, in consequence, the inability to express the necessity to support the right cause to maintain the elements of heritage) definitely and objectively cause more damage to both substance, which is technically unprotected and to social understanding of the problem, while it is perceived as neglect and claimed nonimportant.

"The Forms of Preservation and Activation of Relics of Medieval Castles in Greater Poland and Kujavia" included the social aspect as a core element of its program. The research contains the examination of the social background of the so-called "weak monuments", verification of mechanisms of enhancement and intervention related to selected sites in architecture, urban design and town planning, the review of current methodology (or methodologies) and proposal of flexible strategies. The intention is to superpose all these layers and attempt to construct a coherent structure that will make the understanding of the complex spatial fabric related to history, society and heritage protection more easy to handle. The final conclusion, which is still ahead of the research team, will be based on the development of case studies, project proposals being the implementations of a wide variety of strategies - one integrated system (cf. Barelkowski [8]). The strategies should become manifestations of programs of intervention, which are value-based and individually altered and consulted with the interested representatives of the local community (non-restricted group).

Currently, however, the majority of the social aspects of research have been done and elaborated, with only a small part of data still under processing. The concept of social participation in preservation policy has been ideologically explained in previous sections of this work. Practical implementation requires, however, precise planning of "how?" and "when?". Research may be divided into two phases - one dedicated to the diagnosis of current relations between 


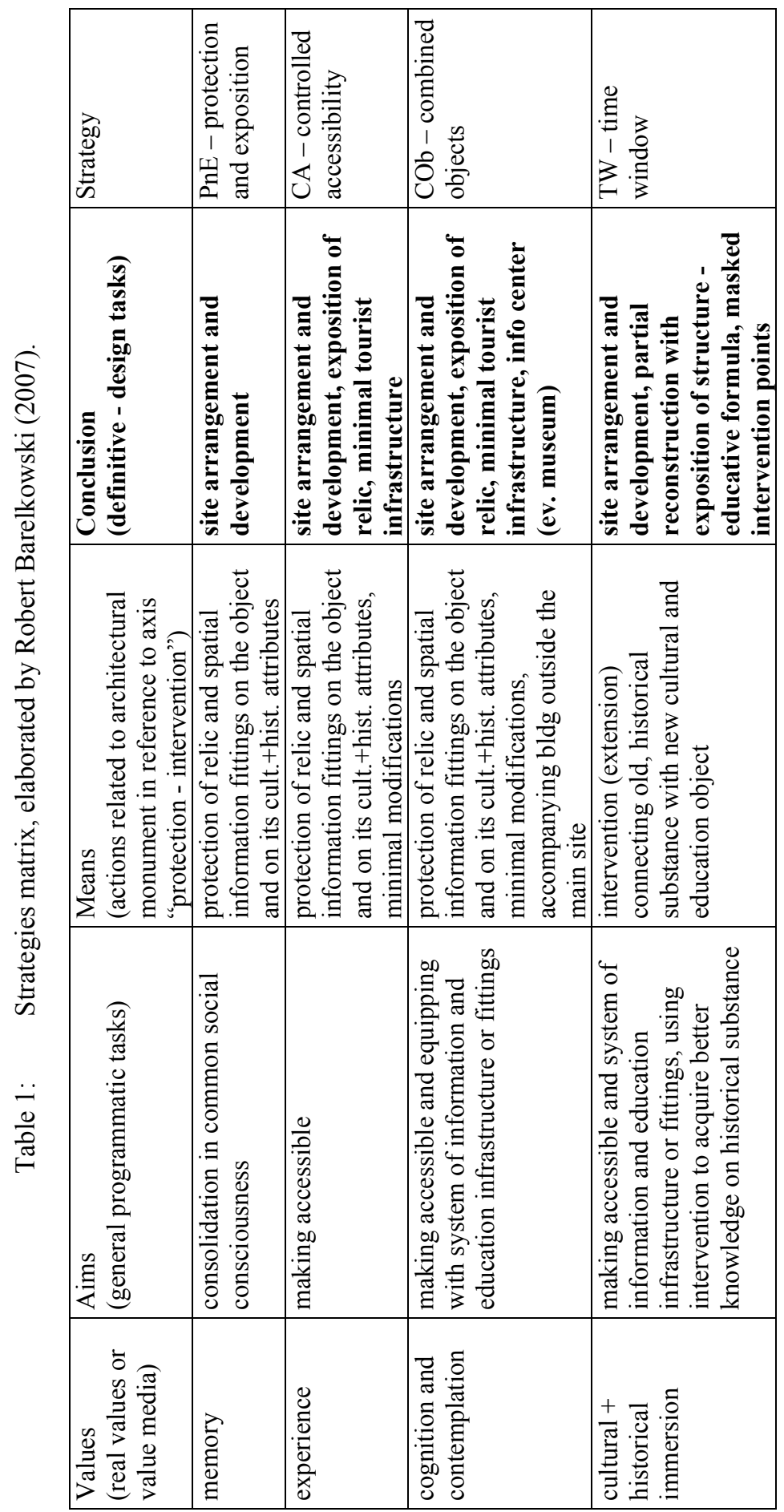

WIT Transactions on Ecology and the Environment, Vol 122, (C) 2009 WIT Press www.witpress.com, ISSN 1743-3541 (on-line) 


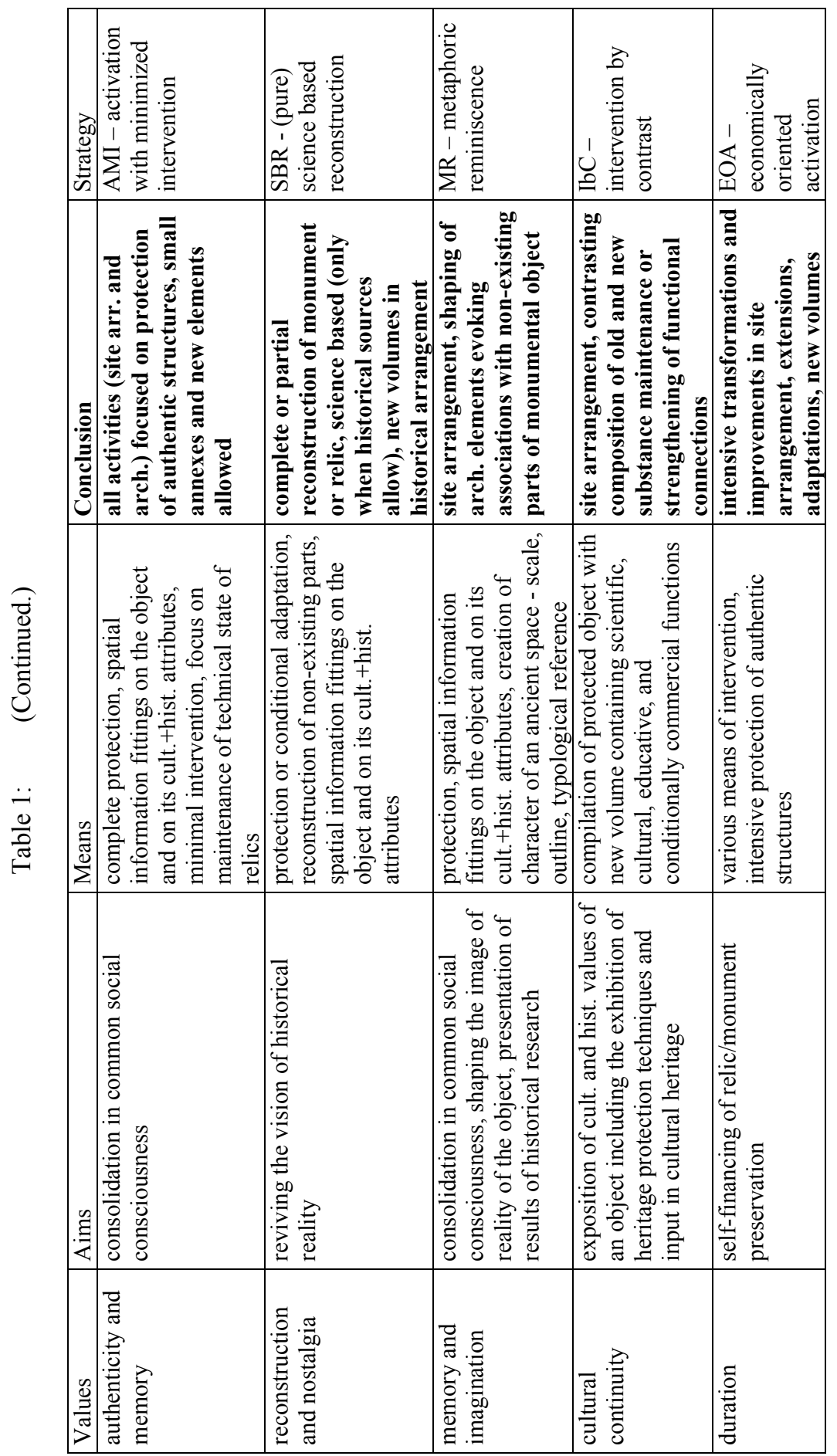

WIT Transactions on Ecology and the Environment, Vol 122, (C) 2009 WIT Press www.witpress.com, ISSN 1743-3541 (on-line) 
society and the environment, the other one concentrated on the formulation of particular proposals to exemplify the principles of a selected strategy. The first phase requires acquisition of data from multiple sources, inhabitants, administration, conservators' offices, among others. Here, as Barelkowska outlines the work of the team [9], both short inquiries and detailed queries have been directed to respondents and representatives of the administration in order to allow for visualization of socio-cultural background and at the same time to investigate the strictly limited possibilities most of the examined small communities have.

The second phase (not launched yet) will be more bilateral, involving more dialogue among the interested parties. These steps will include the discussion on the programs of intervention (few of them already underway), meetings or working sessions, evaluation of proposals of intervention and establishing public discourse among community members.

To answer "why?" it can be pointed out that social participation is aimed at reusing both the object and space, assuring the safety of historical components, yet programming the reuse of the object or its surrounding to reintroduce it into the community's everyday life. It is believed, and it can also be confirmed now upon the analysis of the inquiries alone, that the cultural, educational and economic aspects of protection of these remote and relatively unknown (to a wider public) objects cannot be properly protected if they are planned to preserve the unwanted, "third class" parts of heritage sustained or largely supported by central administration only.

What kind of a view emerges from the inquiries and, partially, from the queries? Particularly informative are inquiries. Although the examination could not be restricted to "a representative sample" of the local communities due to the differences between 11 locations and the will to increase the number of returned forms to maximum, the responses from many distant places often indicate similar tendencies and similar opinions related to the condition of a protected object. The inquiry (prepared under the guidance of Barelkowski was made by Barelkowska, Migda and Morisson in the Institute of Architecture and Urban Design, University of Economy in Bydgoszcz - WSG) contained eight questions with predefined answers (with option to write respondent's own proposal). The questions covered a variety of issues, starting from checking the knowledge of history of the place, opinion on the condition of the castle and its surroundings, to the emotional perception of the status of the castle as well as economic mechanisms respondent would be willing to accept or would point out in order to help in the maintenance of the piece of heritage.

Questions one and six can be somehow connected, in a sense that the first determines historical knowledge of the answering person, while the latter shows his/her opinion on the kind of activities that shall be initiated or improved to increase and improve a positive influence the castle and its surroundings have on both spatial arrangement and socio-cultural life of the community. Only in three examples out of eleven (Kruszwica, Kolo, Wenecja) a significant group declared knowledge on the history of the place above average. At the same time, in the majority of cases, the information policy, lack of printed documents which 

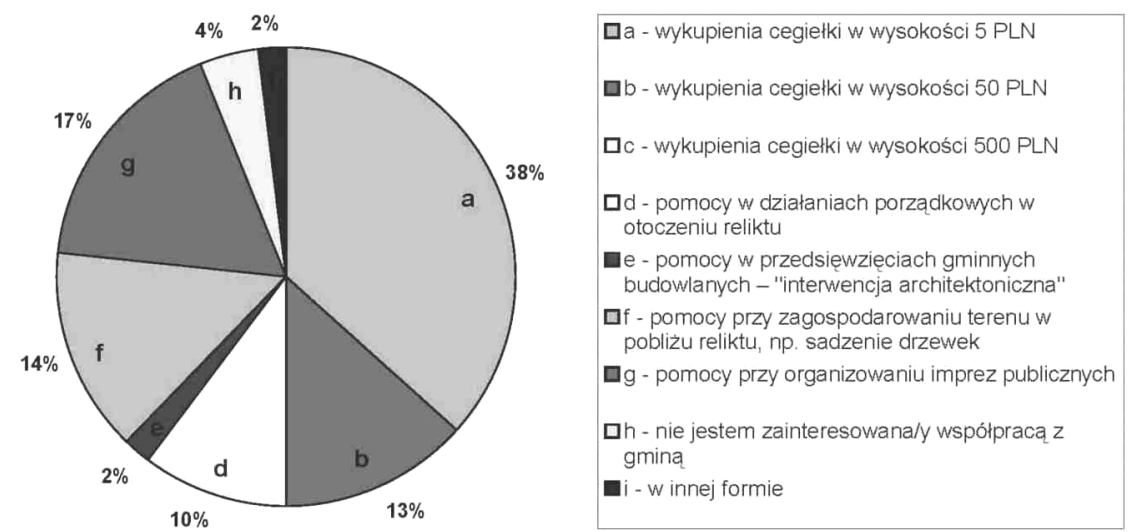

Figure 2: Excerpt from inquiry data processing. Szubin, consent to participate in the process of protection - a) 38\% donation ca. 1,50 EUR, g) $17 \%$ participation in community support organization, f) $14 \%$ participation in site arrangement - physical work.

expand historical background of castles, lack of proper information in the area were to be named as fields of the most urgent actions to be undertaken. Another interesting comparison can be made between the answers to questions two and five, related to - respectively - evaluation of the influence of the castle and definition of emotional connection of a respondent to the castle. For the understanding of how much the absence of the relics affects social consciousness and sensitivity related to architectural heritage, it is very instructive to compare the answers to questions seven and eight, where people were asked whether they'd be willing to participate in the process of transformation of the surroundings of the castle to improve their quality and what fee would they accept, when established, to support the budget of the site and support maintenance and conservation efforts. This particular issue - the questions related to social activity, even if only potential - expose how strong a visual image of the castle affects goodwill and understanding of public interest represented here by the objects of architectural heritage.

It explores the motif, similar to the one described by Bell [10], of gradual shaping or disappearing (in the case of forgotten pieces of heritage) of abstract representation of the object. This process of mythologization, as Bell names it, is a prerequisite for successful orientation of any social group to acquire their support in the effort of protection of ancient example of architectura militaris (but any other example as well).

The inquiries expose also other clear relationship between social remembrance and consciousness and the feeling of responsibility among the members of society. Two places, Danaborz and Szubin, are similar in many ways. The castle in Danaborz was probably erected around mid-15th century as the private seat of a noble family, typical in those times. The history of this 


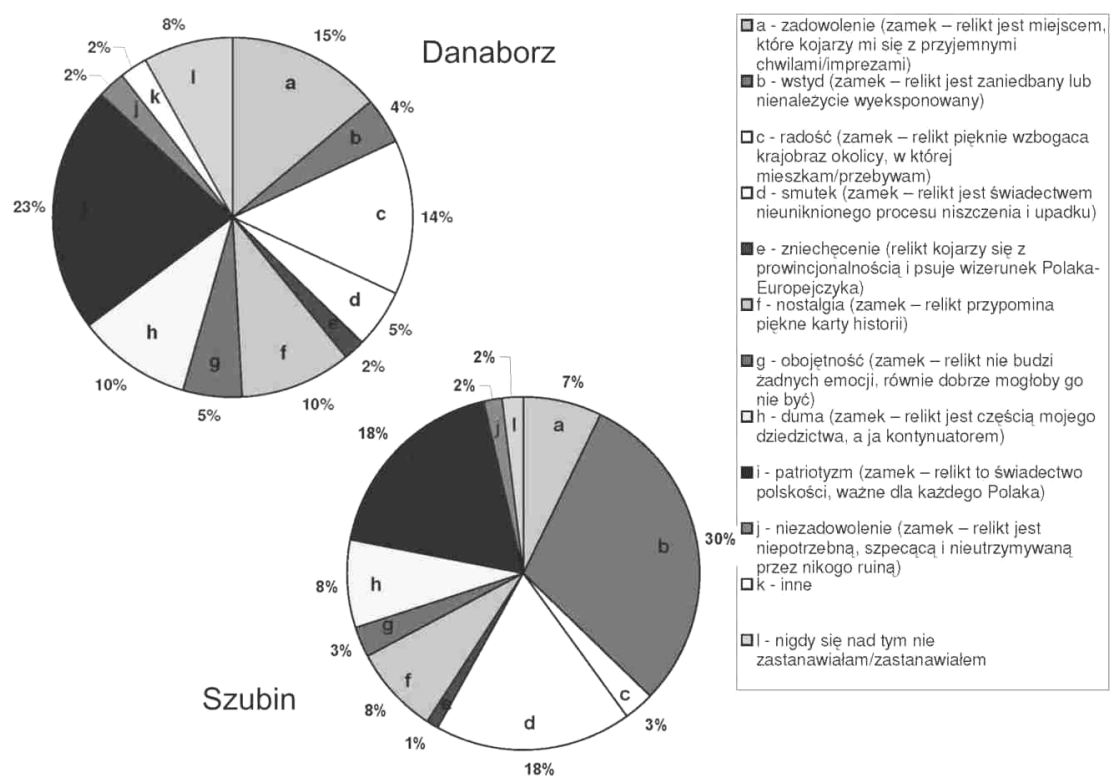

Figure 3: Excerpt from inquiry data processing. Danaborz (up left) and Szubin (bottom right), emotions evoked; a) content, b) shame, d) sadness, 1) never considered.

object is not studied thoroughly, but two researchers, Sikorski and Cnotliwy, were able to extract basic evidence of habitable tower constructed on large stone foundation with a likely outline of the walls and unconfirmed mansion included [11]. Today, the castle is buried in ground, hidden in a cone-like hummock. Szubin origins go back to the 14th century. It was also a seat of a wealthy knight, allegedly Sedziwoj Paluka, on a regular scheme. Extended in the 16th century it lasted only a hundred years, when it was destroyed [12]. The degree of preservation of relics is comparable, there are "few bricks" more in Szubin, but the exposition and presence in literature and the media affects its recognition. Whereas the inhabitants of Danaborz claim they are either satisfied that they have a castle (author's comment - in such a ruin!) or they are not interested in it or never thought about it, the people from Szubin rather feel shame and sadness. It's not only emotional question, because - when comparing potential access to be involved in any activity as an act of charity for renovation or settlement of the area around the castle, again Szubin inhabitants are more willing to commit themselves, than their counterparts from Danaborz. The described tendency was also observed in other similar cases, following that pattern.

Now, the results of inquiries constitute a crucial component for programming the intervention, which does not necessarily mean an intervention affecting the structure itself - it is not yet determined, and a subject of further social and expert (e.g. conservators' office) consultancy. 


\section{Premises for future reactivation}

The research program seeks how to replace the current, unsuccessful mechanisms of maintaining the objects of architectural heritage. How to overcome negative distinction of "more and less valuable" objects? How to achieve efficient protection without the necessity to exploit ancient buildings and valuable sites, without generating an enormous flow of visitors, without the problem of spending the obtained financial means to cover the destruction brought by tourist activities? Even if artistic value or cultural value is not very high, the socio-cultural value should not be underestimated.

It is hard to say, how the activation of a community would work in reality, because for now it is too soon to think about that kind of involvement. But the connection between memory, imagination and imaginative representation of the environment, and physical attributes of architectural object can be reinforced or reestablished, in some cases becoming the only possible method of saving many forgotten and remote historical sites and architectural objects.

Participation may and should play an additional role. Its critical implementation (indirect, filtered by professional knowledge and expertise) changes the status of that kind of sites from exclusive and characterless to emotionally moving and interesting. Public interest, if properly controlled, increases the sense of responsibility for common heritage, with educative, individual and social benefits.

The members of the research team look with some uncertainty, but with much hope raised by the current, partial results, expecting that the examined relations and elaborated mechanisms including strategy matrix will be able to contribute to the improvement of preservation methods.

\section{References}

[1] Malachowicz, E., Konserwacja i rewaloryzacja architektury w zespolach $i$ krajobrazie, Oficyna Wydawnicza Politechniki Wroclawskiej: Wroclaw, 1994.

[2] Jokilehto, J., A History of Architectural Conservation, Butterworth Heinemann: Oxford, 2002.

[3] Barelkowski, R., Restytucja Zamku Krolewskiego w Poznaniu. Zagadnienie urbanistyczne, architektoniczne $i$ spoleczne $w$ teorii lokalizacji i zastosowaniach, Osrodek Wydawnictw Naukowych: Poznan, 2003.

[4] Barelkowski, R., Society, Identity, and Architectural Heritage, Proc. of the Baltic Rim Seminar. The Sustainability and Development of Cultural Quarters, ed. M. Legner \& D. Ponzini, Department of Integrated Conservation, Gotland University, Visby, Sweden, 2008.

[5] Luxen, J.-L., Section 2 - summary, Dziedzictwo kulturowe fundamentem rozwoju cywilizacji, Proceedings from International Conference on Conservation Krakow 2000, Politechnika Krakowska: Krakow, pp. 115$119,2000$. 
[6] Benedetti, A., Some Comments on the Evolution of the Basic Principles of Protection, Dziedzictwo kulturowe fundamentem rozwoju cywilizacji, Proceedings from International Conference on Conservation Krakow 2000, Politechnika Krakowska: Krakow, pp. 351-352, 2000.

[7] Bogdanowski, J., Problem wartosci i znaczenia w zespolach zabytkowych, Aktywizacja obiektow i zespolow architektury zabytkowej, Proceedings from International Symposium in Pszczyna, PAN Katowice, Politechnika Slaska w Gliwicach, Muzeum Wnetrz Zabytkowych w Pszczynie: Gliwice, pp. 18-27, 1991.

[8] Barelkowski, R., Projektowe metody definiowania kierunkow ochrony i ingerencji w zabytkowa architekture militarna, Ochrona Zabytkow Architektury Obronnej - Teoria a praktyka, ed. M. Lewicka, Polski Komitet Narodowy Miedzynarodowej Rady Ochrony Zabytkow ICOMOS, Wydzial Architektury Politechniki Warszawskiej, Burmistrz Miasta Dzialdowo: Dzialdowo, pp. 78-83, 2008.

[9] Barelkowska, K., Socio-cultural environment in the surrounding of a monument. The aim and the structure of inquiries. EKO Architektura Urbanizm Studia, ed. L. Zimowski, Wyzsza Szkola Gospodarki w Bydgoszczy: Bydgoszcz, pp. 6, 2009 (in edition).

[10] Bell, B., Myth, Culture and Landscape: Classical Identity and Interpretive Design at St. Bertrand de Comminges, Architectural Research, ed. L. Fontein, Proc. from 3rd ARCC/EAAE International Conference, McGill University: Montreal, pp. 96-105, session 14, 2002.

[11] Kajzer, L., Kolodziejski, S. \&Salm, J., Leksykon Zamkow w Polsce, Arkady: Warszawa, 2001.

[12] Guerquin, B., Zamki w Polsce, Arkady: Warszawa, 1984. 